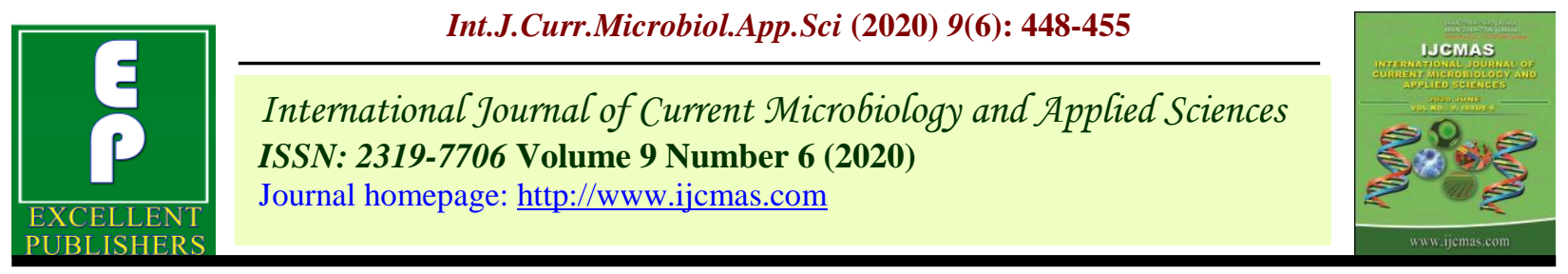

Original Research Article

https://doi.org/10.20546/ijcmas.2020.906.059

\title{
Intercropping of Different Vegetable Crops in New Cashew Plantation under Konkan Conditions of Maharashtra, India
}

\author{
R. C. Gajbhiye*, S. N. Pawar, V. K. Zote and B. N. Sawant \\ Regional Fruit Research Station, Vengurla - 416 516, Dist. Sindhudurg (M.S.), India \\ *Corresponding author
}

\section{A B S T R A C T}

An experiment was conducted at Regional Fruit Research Station, Vengurla-416 516, Dist. Sindhudurg (Maharashtra) with an objective to study the performance different

\section{Keywords}

Brinjal, Cashew,

Chilli, Cowpea,

Intercropping and

Yardlong bean

Article Info

Accepted:

15 May 2020

Available Online:

10 June 2020 vegetable crops in new cashew plantation under Konkan condition of Maharashtra under AICRP-Cashew programme during the year 2018-19. The experiment was laid out with 5 treatments viz., Yardlong bean $\left(\mathrm{T}_{1}\right)$, Bhendi $\left(\mathrm{T}_{2}\right)$, Cowpea $\left(\mathrm{T}_{3}\right)$, Chilli $\left(\mathrm{T}_{4}\right)$, Brinjal $\left(\mathrm{T}_{5}\right)$ and Control (Cashew alone) under Randomized block design with five replications. The recommended package of practices including the recommended dose of fertilizers and plant protection was simultaneously followed for both main crop cashew and vegetable crops. Among the different intercrops tried during initial year of cashew plantation, Cashew + Yardlong bean intercropping system produced significantly the highest total yield (4.98 t/ha), cashew equivalent yield $(4.41 \mathrm{t} / \mathrm{ha})$, LER (1.73 t/ha), net returns (Rs.4,88,702/-) with highest B:C ratio (3.35). The Yardlong bean followed by Cowpea intercropping system showed the highest gain of $\mathrm{N}, \mathrm{P}$ and $\mathrm{K}$ in soil as compared to other intercropping system and sole cashew. In present investigation, Yardlong bean appeared as a best intercrop in fresh cashew plantation for getting the higher returns during Rabi season in Konkan region.

\section{Introduction}

Cashew (Anacardium occidentale L.) is one of the most important dollar earning crops of Konkan region of Maharashtra which is being widely cultivated on an area of about 1.91 lakh ha with production of 2.69 lakh MT (Anon., 2017). Cashew starts fruiting 2-3 years after planting in vegetative propagated trees. Cashew nut is normally planted at $7 \mathrm{x} 7$ $\mathrm{m}$ spacing as such there is ample scope for growing of vegetable crops during initial years particularly during Rabi season. Growing of crops in the interspaces of the orchard not only generates extra income but the practice also helps to check the soil erosion through ground coverage and improves the soil physic-chemical condition.

Selection of suitable intercrops in cashew orchard for maximum return as well as to improve the soil fertility status mainly depends on agro-climatic condition of the cultivation area. Although there are many 
reports of intercropping models in many fruit crops under different agro-climatic condition (Sarkar et al., 2004; Ghosh and Pal, 2010)

Cashew nut is a perennial crop and farmers earn money only once in the year. Further, the land and other resources are being utilized only for sole crop of cashew nut. Farmers need the additional income from the same land with growing suitable crops without hampering the yield of cashew nut. It also helps as an insurance against main crop failure under adverse condition. Intercrop system utilizes resources efficiently to increase the productivity. A systematic intercropping system involving compatible crops with varying morphological and rooting habits will enable better resource use and more returns (Salam and Peter, 2010).

Vegetable crops are herbaceous plants having parts like pods, fruits, modified roots, underground stems and leaves that are used for food. These vegetable crops are short durational species, which are most suitable for intercropping in comparison to other species. Intercropping is based on the principle of efficient utilization of canopy space available in fruit orchard. This practice has many advantages for fruit growers including the generation of additional income, improving food security and preventing soil erosion through orchard floor covers. Further, the organic matters added from intercrops improve soil fertility and make the intercropping based agri-horti system ecologically sustainable and economically feasible to the farmers (Upadhyaya et al., 1994). In addition to this it has significant role in increasing the productivity and improvement of health of the orchards. Bhatnagar et al., (2007) had also proposed the intercropping as one of the techniques of land utilization for optimum production. Intercropping of vegetables like, cucumber, ridge guard, bitter guard, snake guard and sponge guard in the initial period of orchard during kharif season is recommended for Konkan region. However, feasibility of intercropping of vegetables in cashew orchard during Rabi season has not been studied so far in the Konkan region. Hence, an experiment was conducted to study the performance of vegetable crops as an intercrop in young cashew nut plantation at Cashew Farm, Regional Fruit Research Station, Vengurla in Sindhudurg district.

\section{Materials and Methods}

An experiment was conducted during the year 2018-19 under AICRP-Cashew programme at Regional Fruit Research Station, Vengurla416 516, Dist. Sindhudurg (Maharashtra). The soil of the experimental field was lateritic sandy clay loam in texture with acidic in reaction. The experiment was laid out with 5 treatments viz., $\mathrm{T}_{1}-$ Cashew + Yardlong bean (Wali) (Vigna unguiculata sp. sesquipedalis), $\mathrm{T}_{2}$ - Cashew + Bhendi (Abelmoschus esculentus), $\mathrm{T}_{3}-$ Cashew + Cowpea (Vigna unguiculata), $\mathrm{T}_{4}$ - Cashew + Chilli (Capsicum annum), $\mathrm{T}_{5}-$ Cashew + Brinjal (Solanum melongena) and Control (Cashew alone) under randomized block design with five replications. Grafts of cashew cv. Vengurle-9 planted in 2017 at $7 \mathrm{~m} \times 7 \mathrm{~m}$ (200 plants/ha) for present experimentation.

The recommended package of practices including, recommended dose of fertilizers and plant protection schedule were followed for both main and intercrops. Similarly irrigation and other inter-culture operations were followed for intercrops at regular interval. The total area planted with intercrop/ha was 4900 sq. m. and total number of intercrop plots per ha was 196. The effective space area available under cashew orchard was common for the entire vegetable crops i.e. $25 \mathrm{~m}^{2}$, out of total available area in between four cashew tree $49 \mathrm{~m}^{2}$. All the inter 
crops were sown during Rabi season i.e. fortnight of November by adopting the recommended spacing and package of practices. The details of vegetable crops as intercrops plantation are given in Table 1. Initial and final (after harvest) physical and chemical properties of soil were analyzed. The various yields attributes such as yield of intercrop ( $\mathrm{kg} / \mathrm{plot}, \mathrm{q} / \mathrm{ha} \& \mathrm{t} / \mathrm{ha})$, yield of cashew (kg/tree, q/ha \& $\mathrm{t} / \mathrm{ha})$, cashew equivalent yield (t/ha), land equivalent ratio, total yield (t/ha) and comparative economics and $\mathrm{B}$ : $\mathrm{C}$ ratio was recorded during the investigation period. The data was statistically analyzed by following the procedure given by Panase and Sukhatme (1995).

\section{Results and Discussion}

The results and discussions are summarized under following heads

Yield performance of cashew nut $\left(\mathrm{kg} \mathrm{tree}^{-1}\right.$, $\left.\mathrm{q} \mathrm{ha} \mathbf{h}^{-1} \& \mathrm{t} \mathrm{ha}^{-1}\right)$ in different intercropping and as sole crop

Data on yield of cashew nut $\left(\mathrm{t} \mathrm{ha} \mathrm{h}^{-1}\right)$ in different intercropping and as sole recorded during 2018-19 are presented in Table 2. It is revealed from the data that the cashew yield was significantly varied during investigation period.

The treatment $T_{1}$ recorded significantly the highest yield of cashew cv. Vengurla-9 after $2^{\text {nd }}$ year plantation $(2.86 \mathrm{~kg} /$ tree, $5.72 \mathrm{q} / \mathrm{ha} \&$ $0.572 \mathrm{t} / \mathrm{ha}$ ) however; it was found at par with treatment $\mathrm{T}_{3}(2.59 \mathrm{~kg} /$ tree, $5.19 \mathrm{q} / \mathrm{ha} \& 0.519$ t/ha). While, the lowest yield obtained in treatment $\mathrm{T}_{2}(1.18 \mathrm{~kg} /$ tree, $2.36 \mathrm{q} / \mathrm{ha} \& 0.236$ t/ha).

In overall, treatment $\mathrm{T}_{1}$ (Cashew + Yard long bean) had recorded significantly the highest yield and followed in $\mathrm{T}_{3}$ (Cashew + Cowpea). The present results i.e. increased cashew yield in $T_{1}$ and $T_{3}$ may be because of Yard long bean and cowpea are the leguminous crop and they fixes the atmospheric nitrogen that might have further available to the cashew plant and result into higher cashew yield in both the treatments. Further the synergistic effect of both crops may increase the cashew yield. While, the low yield cashew recorded in treatment $\mathrm{T}_{2}$ (Cashew + Bhendi). Yield of cashew intercropped with Yardlong bean was recorded higher than those intercropped with Bhendi. The lower yield of cashew intercropped with Bhendi was due to the high incidence of yellow vein mosaic (YVM) during the investigation period. Similar results also reported by Asandhi (1994) that the yield of potato intercropped with Yardlong bean was higher than those intercropped with corn or sweet potato. The lower yield of potato intercropped with sweet potato was due to the high incidence of bacterial wilt.

Intercropping of vegetable crops under canopy of fruit trees does not has negative impact on growth, flowering, fruiting and yield of trees. The effects on growth of the plants in intercrops did not interfere with the growth of main crop but the fertilizer application of main crop and intercrop must be practiced (Taweekiat et al., 1989). Intercropping of the vegetables under fruit orchard is based on the resource use maximization (RUM), which has significant impact on productivity and health improvement of fruit trees and generate additional income to farmers (Singh and Sharma, 2016). Abdel-Aziz et al., (2008) confirmed enhancement of fruit set, vegetative growth and fruit yield with reduced fruit drop in citrus when Egyptian clover and Fenugreek cover crop were grown as intercrop. Chowdhury and Deka (1997) obtained the highest coconut yield (8365 nuts/ha) by practice of Coconut + Betel wine $(\mathrm{P}$. betle $)+$ Banana + Assam lemon + 
turmeric + Colocasia cropping system). Kumar et al., (2000) reported tomato as the most efficient intercrop and resulted highest yield of papaya; the research findings are in agreement with present investigation.

Yield performance vegetable crops as a intercrop in cashew plantation

The data of intercrops grown cashew plantation are presented in Table 2. The data revealed that, $\mathrm{T}_{1}$ (Yardlong bean) recorded significantly the highest yield $(76.01 \mathrm{~kg} / \mathrm{plot}$, 148.98 q ha \& $14.898 \mathrm{t} / \mathrm{ha}$ ) and superior over rest of the treatments. The next best crop was Brinjal $\left(\mathrm{T}_{5}\right)$ which recorded the second best yield $(38.99 \mathrm{~kg} / \mathrm{plot}, 76.41 \mathrm{q}$ hha \& $7.64 \mathrm{t} / \mathrm{ha})$

In present investigation, significantly the highest yield was recorded by Yardlong bean. In an intercrop system with beans and peas, there has been increased yield presumably by the transfer of biologically fixed nitrogen from the roots of legume to the root zone of the companion crop. Similar results also reported in banana intercropping with vegetables by Akyeapong et al., (1999) and Gold et al., (1999). Sharma (1999) reported that Brinjal produced the highest marketable fruit yield under both open and shaded conditions $(319.10$ and $62.69 \mathrm{q} / \mathrm{ha}$, respectively) in 5-year-old mango (cv. Langra) trees.

\section{Land equivalent ratio (LER)}

Data on land equivalent ratio (t/ha) of the intercropping system presented in Table 3 observed that Cashew + Yardlong bean $\left(\mathrm{T}_{1}\right)$ recorded the highest (1.73) land equivalent ratio (LER) and superior over rest of the treatments. All intercropping systems recorded average LER more than one indicating that these intercropping system is advantageous. Higher values of LER under cashew based intercropping system were due to satisfactory yield of vegetable crops. Productivity in terms of the LER was higher in all the intercropping systems than sole cashew, suggesting that intercropping is a more efficient land use system during initial year of cashew plantation. Present findings are in conformity with the results reported by Vikram et al., (2015) in cashew based intercropping system. Abd El-Gaid et al., (2014) reported highest LER in 1:3 tomato and common bean planting system as 1.26 and 1.25 in first and second season, respectively.

\section{Cashew equivalent yield (t/ha)}

With regards to cashew equivalent yield (t/ha) (Table 3), Cashew + Yardlong bean $\left(\mathrm{T}_{1}\right)$ recorded significantly the highest cashew equivalent yield (4.41 t/ha) and superior over rest of the treatments. Vikram et al., (2015) reported that the highest total cashew equivalent yield $(6659 \mathrm{~kg} / \mathrm{ha})$ with turmeric followed by garlic $(5608 \mathrm{~kg} / \mathrm{ha})$. Anburani and Vidhya Priyadharshini (2011) reported significant increase in equivalent yield when jasmine intercropped with vegetable cowpea; are in agreements with present results.

\section{Total yield (t/ha)}

Total yield of intercropping system (t/ha) (cashewnut yield + cashewnut equivalent yield) in cashew nut plantation are presented in 3. It is evident from the data that Cashew + Yardlong bean $\left(\mathrm{T}_{1}\right)$ recorded significantly the highest total yield (4.98 t/ha) and superior over rest of the treatments.

\section{Economics}

In intercropping, lot of methodology has been developed for comparison. However, the most convincing is monetary return from suggested cropping system. Economics of different intercropping systems (Table 4) in cashewnut 
revealed that the Yardlong bean intercropping noticed the highest net returns of Rs. $4,88,702 /$ - per ha with $\mathrm{B}: \mathrm{C}$ ratio of 3.35 followed by Cashew + Brinjal intercropping with net return of Rs. 2,47,830/- per ha and $\mathrm{B}: \mathrm{C}$ ratio 2.95. Higher cost: benefit ratio obtained due to intercropping than the cashew as sole crop alone was in accordance to observation recorded in several other investigations (Bhuva et al., 1985; Rajput et al., 1986; Kashyap et al., 1989). The present finding was in agreement with the results of Vikram et al., (2015) obtained the highest net profit from cashew based intercropping system with turmeric (2.151 lakhs/ha) followed by garlic (1.832 lakhs/ha). However, the $\mathrm{B}: \mathrm{C}$ ratio was the maximum for chilli (3.78) followed by fenugreek (3.47), garlic (3.20) and turmeric (2.17) compared to the minimum in coriander $(0.73)$.

Singh et al., (2015) had reported high gross and net income in turmeric (Rs. 1,39,720/ha and Rs. 1,08,210/ ha), bunda (Rs. 1,12,050/ha and Rs. 93,250/ha), and Arvi (Rs. 1,04,670/ha and Rs. 86,350/ha) in guava plantation as compared to guava grown as sole crop (Rs. $68,650 / \mathrm{ha})$. Higher gross income has also been recorded from the various intercrops under papaya plantation (Gadre, 1997).

Table.1 Details of intercrop plantation at Vengurla centre

\begin{tabular}{|c|l|l|c|c|c|c|}
\hline $\begin{array}{c}\text { Tr. } \\
\text { No. }\end{array}$ & \multicolumn{1}{|c|}{ Treatment } & \multicolumn{1}{|c|}{ Variety } & $\begin{array}{c}\text { Plot size } \\
\left(\mathbf{m}^{\mathbf{2}}\right)\end{array}$ & $\begin{array}{c}\text { Spacing } \\
(\mathbf{c m})\end{array}$ & $\begin{array}{c}\text { Duration } \\
\text { (Days) }\end{array}$ & $\begin{array}{c}\text { No. of } \\
\text { harvest }\end{array}$ \\
\hline $\mathbf{T}_{\mathbf{1}}$ & Cashew + Yardlong bean & Konkan Wali & 25 & $60 \times 60$ & 166 & 28 \\
\hline $\mathbf{T}_{\mathbf{2}}$ & Cashew + Bhendi & Konkan Uphar & 25 & $60 \times 60$ & 137 & 10 \\
\hline $\mathbf{T}_{\mathbf{3}}$ & Cashew + Cowpea & Konkan Sadabahar & 25 & $45 \times 30$ & 121 & 10 \\
\hline $\mathbf{T}_{\mathbf{4}}$ & Cashew + Chilli & Konkan Kirti & 25 & $60 \times 45$ & 131 & 10 \\
\hline $\mathbf{T}_{\mathbf{5}}$ & Cashew + Brinjal & Konkan Prabha & 25 & $60 \times 60$ & 190 & 16 \\
\hline $\mathbf{T}_{\mathbf{6}}$ & Cashew (Control) & Vengurle-9 & - & $7 \mathrm{~m} \times 7 \mathrm{~m}$ & - & - \\
\hline
\end{tabular}

Table.2 Yield of cashew and intercrops in intercropping system

\begin{tabular}{|c|c|c|c|c|c|c|c|}
\hline \multirow{2}{*}{$\begin{array}{l}\text { Tr. } \\
\text { No. }\end{array}$} & \multirow[t]{2}{*}{ Treatments } & \multicolumn{3}{|c|}{ Yield of intercrop } & \multicolumn{3}{|c|}{ Yield of cashew } \\
\hline & & kg/plot & quha & t/ha & kg/tree & qua & t/ha \\
\hline $\mathbf{T}_{1}$ & $\mathrm{C}+$ Yardlong bean & 76.01 & 148.98 & 14.898 & 2.86 & 5.72 & 0.572 \\
\hline $\mathbf{T}_{2}$ & $\mathrm{C}+$ Bhendi & 20.05 & 39.29 & 3.929 & 1.18 & 2.36 & 0.236 \\
\hline $\mathbf{T}_{\mathbf{3}}$ & $\mathrm{C}+$ Cowpea & 9.55 & 18.71 & 1.871 & 2.59 & 5.19 & 0.519 \\
\hline $\mathbf{T}_{4}$ & $\mathrm{C}+$ Chilli & 12.18 & 23.88 & 2.388 & 1.69 & 3.38 & 0.338 \\
\hline $\mathbf{T}_{5}$ & $\mathrm{C}+$ Brinjal & 38.99 & 76.41 & 7.641 & 1.78 & 3.57 & 0.357 \\
\hline $\mathbf{T}_{6}$ & Cashew alone & 0 & 0 & 0 & 1.53 & 3.06 & 0.306 \\
\hline & S.Em. \pm & 3.63 & 7.10 & 0.71 & 0.32 & 0.68 & 0.064 \\
\hline & C.D. @ 5\% & 10.87 & 21.29 & 2.13 & 0.95 & 2.06 & 0.19 \\
\hline
\end{tabular}


Table.3 Land Equivalent Ratio (LER), Cashew nut equivalent yield and total yield of intercropping system in cashew nut plantation

\begin{tabular}{|c|l|c|c|c|}
\hline $\begin{array}{c}\text { Tr. } \\
\text { No. }\end{array}$ & \multicolumn{1}{|c|}{ Treatments } & $\begin{array}{c}\text { LER } \\
\text { (t/ha) }\end{array}$ & $\begin{array}{c}\text { Cashew nut equivalent } \\
\text { yield (t/ha) }\end{array}$ & $\begin{array}{c}\text { Total yield } \\
\text { (t/ha) }\end{array}$ \\
\hline $\mathbf{T}_{\mathbf{1}}$ & C + Yardlong bean & 1.73 & 4.41 & $\mathbf{4 . 9 8}$ \\
\hline $\mathbf{T}_{\mathbf{2}}$ & C + Bhendi & 1.30 & 1.73 & $\mathbf{1 . 9 7}$ \\
\hline $\mathbf{T}_{\mathbf{3}}$ & C + Cowpea & 1.16 & 0.85 & $\mathbf{1 . 3 6}$ \\
\hline $\mathbf{T}_{\mathbf{4}}$ & C + Chilli & 1.10 & 0.70 & $\mathbf{1 . 0 4}$ \\
\hline $\mathbf{T}_{\mathbf{5}}$ & C + Brinjal & 1.11 & 2.26 & $\mathbf{2 . 6 2}$ \\
\hline $\mathbf{T}_{\mathbf{6}}$ & Cashew alone & 1.00 & 0.00 & $\mathbf{0 . 3 1}$ \\
\hline & S.Em.土 & 0.10 & 0.21 & $\mathbf{0 . 2 3}$ \\
\hline & C.D. @ $\mathbf{5 \%}$ & $\mathbf{0 . 3 0}$ & $\mathbf{0 . 6 3}$ & $\mathbf{0 . 6 8}$ \\
\hline
\end{tabular}

Table.4 Economics of different intercropping systems in cashew nut plantation

\begin{tabular}{|c|c|c|c|c|c|c|c|c|c|}
\hline \multirow{2}{*}{$\begin{array}{l}\text { Tr. } \\
\text { No. }\end{array}$} & \multirow[t]{2}{*}{ Treatments } & \multirow{2}{*}{$\begin{array}{c}\text { Yield of } \\
\text { inter-crop } \\
\text { (t/ha) }\end{array}$} & \multirow{2}{*}{$\begin{array}{c}\text { Yield } \\
\text { of cashew } \\
\text { (t/ha) }\end{array}$} & \multicolumn{3}{|c|}{ Cost of Cultivation (Rs./ha) } & \multicolumn{2}{|c|}{ Returns (Rs./ha) } & \multirow{2}{*}{$\begin{array}{c}\text { C:B } \\
\text { Ratio }\end{array}$} \\
\hline & & & & Cashew & $\begin{array}{l}\text { Inter- } \\
\text { crop }\end{array}$ & $\begin{array}{c}\text { Cashew } \\
+ \\
\text { Intercrop }\end{array}$ & $\begin{array}{c}\text { Gross } \\
\text { return } \\
\text { (Rs./ha ) }\end{array}$ & $\begin{array}{l}\text { Net return } \\
\text { (Rs./ha ) }\end{array}$ & \\
\hline $\mathrm{T}_{1}$ & $\begin{array}{l}\mathrm{C}+\text { Yardlong } \\
\text { bean }\end{array}$ & 14.898 & 72 & $64^{\prime}$ & 81062 & 145828 & 634530 & & $1: 3.35$ \\
\hline $\mathrm{T}_{2}$ & $\mathrm{C}+$ Bhendi & 3 & 0.236 & $64^{\prime}$ & 204 & 85 & 251 & & $1: 1.95$ \\
\hline $\mathrm{T}_{3}$ & $\mathrm{C}+$ Cowpea & 1.871 & 0.519 & 64766 & 25732 & 90498 & 92 & & $1: 0.63$ \\
\hline $\mathrm{T}_{4}$ & $\mathrm{C}+$ Chilli & 2.388 & 0.338 & 64766 & 18034 & 82800 & 118335 & 35535 & $1: 0.43$ \\
\hline $\mathrm{T}_{5}$ & $\mathrm{C}+$ Brinjal & 7.641 & 0.357 & 64766 & 19234 & 84000 & 331830 & 247830 & $1: 2.95$ \\
\hline $\mathrm{T}_{6}$ & Cashew alone & 0 & 0.306 & 64766 & 0 & 64766 & 41310 & -23456 & $1:-0.36$ \\
\hline
\end{tabular}

Table.5 Soil analysis data initial \& after harvest under intercropping in cashew trial at Vengurla centre during the year 2018-19

\begin{tabular}{|c|c|c|c|c|c|c|c|}
\hline \multirow{2}{*}{$\begin{array}{l}\text { Tr. } \\
\text { No. }\end{array}$} & \multirow[t]{2}{*}{ Treatments } & \multicolumn{6}{|c|}{ Soil analysis } \\
\hline & & $\underset{(1: 2.5)}{\text { pH }}$ & $\begin{array}{c}\text { EC } \\
\mathrm{dS} \mathrm{m}^{-1}\end{array}$ & $\begin{array}{l}\text { OC } \\
(\%)\end{array}$ & $\begin{array}{c}\mathrm{N} \\
(\mathrm{kg} / \mathrm{ha})\end{array}$ & $\begin{array}{c}\mathbf{P}_{2} \mathbf{O}_{5} \\
(\mathbf{k g} / \mathrm{ha})\end{array}$ & $\begin{array}{c}\mathrm{K}_{2} \mathrm{O} \\
(\mathrm{kg} / \mathrm{ha})\end{array}$ \\
\hline $\mathbf{T}_{1}$ & Yardlong bean & 5.69 & 0.169 & 2.30 & $162.20(\mathrm{~L})$ & $\begin{array}{l}\mathbf{2 6 . 2 0} \\
(\mathrm{MH})\end{array}$ & $\begin{array}{c}370.61 \\
(\mathrm{VH})\end{array}$ \\
\hline $\mathbf{T}_{2}$ & Bhendi & 5.71 & 0.168 & 2.05 & $143.00(\mathrm{~L})$ & $\begin{array}{l}22.85 \\
(\mathrm{MH})\end{array}$ & $\begin{array}{c}356.28 \\
(\mathrm{VH})\end{array}$ \\
\hline $\mathbf{T}_{3}$ & Cowpea & 5.69 & 0.170 & 2.32 & $155.38(\mathrm{~L})$ & $\begin{array}{l}25.83 \\
(\mathrm{MH})\end{array}$ & $\begin{array}{c}369.57 \\
(\mathrm{VH})\end{array}$ \\
\hline $\mathbf{T}_{4}$ & Chilli & 5.70 & 0.168 & 2.18 & $140.98(\mathrm{~L})$ & $\begin{array}{c}21.40 \\
(\mathrm{M})\end{array}$ & $\begin{array}{c}350.49 \\
(\mathrm{VH})\end{array}$ \\
\hline $\mathbf{T}_{5}$ & Brinjal & 5.65 & 0.170 & 2.16 & $141.07(\mathrm{~L})$ & $\begin{array}{c}21.38 \\
(\mathrm{M})\end{array}$ & $\begin{array}{c}353.03 \\
(\mathrm{VH})\end{array}$ \\
\hline \multirow[t]{2}{*}{$\mathbf{T}_{6}$} & Sole Cashew nut & 5.67 & 0.169 & 2.20 & 144.04 & 23.20 & 359.91 \\
\hline & Initial Soil Status & 5.68 & 0.169 & 2.27 & 144.20 & 23.25 & 368.80 \\
\hline
\end{tabular}




\section{Chemical properties of soil}

The initial and final chemical properties of soil i.e. $\mathrm{pH}, \mathrm{EC}$ and organic carbon and available soil $\mathrm{N}, \mathrm{P}_{2} \mathrm{O}_{5}$ and $\mathrm{K}_{2} \mathrm{O}$ was analyzed and presented in Table 5. The soil $\mathrm{pH}$ ranged from $5.65\left(\mathrm{~T}_{5}\right)$ to 5.71 in $\left(\mathrm{T}_{2}\right)$, EC ranged from $0.168 \mathrm{dS} \mathrm{m}^{-1}\left(\mathrm{~T}_{2} \& \mathrm{~T}_{4}\right)$ to $0.170 \mathrm{dS} \mathrm{m}^{-1}$ $\left(\begin{array}{llll}\mathrm{T}_{3} & \& & \mathrm{~T}_{5}\end{array}\right)$ while organic carbon content ranged from $2.05 \%\left(\mathrm{~T}_{2}\right)$ to $2.32 \%\left(\mathrm{~T}_{3}\right)$ and not much changed observed in physical parameter of soil when compared with initial values. It is seen from the data that Cashew + Yardlong bean cropping system recorded maximum available $\mathrm{N}(162.20 \mathrm{~kg} / \mathrm{ha}), \mathrm{P}_{2} \mathrm{O}_{5}(26.20$ $\mathrm{kg} / \mathrm{ha})$ and $\mathrm{K}_{2} \mathrm{O}(370.61 \mathrm{~kg} \backslash \mathrm{ha})$ in soil.

It is also revealed from the data (Table 5) that the Cashew + Yardlong bean $\left(\mathrm{T}_{1}\right)$ and Cashew + Cowpea $\left(\mathrm{T}_{3}\right)$ intercropping systems recorded net positive gain in available $\mathrm{N}, \mathrm{P}$ and $\mathrm{K}$ in soil over initial $\mathrm{N}, \mathrm{P}$ and $\mathrm{K}$ status when compared with other intercropping system and sole cashew nut. Similar results were reported by Tiwari and Baghel (2014) in mango. Swain et al., (2012) reported that the mango + guava + cowpea system improved available nitrogen and potassium in soil. Among the different intercrops tried in young cashew plantation Cashew + Yardlong bean intercropping system produced significantly the highest total yield, cashew equivalent yield, LER, highest net returns with highest $\mathrm{B}: \mathrm{C}$ ratio. Productivity in terms of the LER was higher in all the intercropping systems than sole cashew. The Yardlong bean and followed by Cowpea intercropping system showed the highest available $\mathrm{N}, \mathrm{P}$ and $\mathrm{K}$ in soil. Hence, Yardlong bean appeared as a best intercrop in fresh cashew plantation for getting the higher returns during Rabi season in Konkan region. However, the experiment was conducted first time in the region, to explore this possibility again from 3 to 4 years to achieve at a specific recommendation.

\section{Acknowledgements}

The authors are very grateful to the Director \& PC, ICAR-DCR, Puttur, Karnataka and The Director of Research, Dr .B. S. Konkan Krishi Vidyapeeth, Dapoli (M.S.) for providing financial assistance and facilities during the course of investigation.

\section{References}

Abd El-Gaid, M. A., Al-Dokeshy, M. H. and Nassef, M. T. 2014. Effects of intercropping system of tomato and common bean on growth, yield components and land equivalent ratio in New Valley Governorate. Asian J. of Crop Sci. 6: 254261.

Abdel-Aziz, R. A. A., Salem, S. E. and Al-Bitar, L. 2008. Effect of inter-cropping cover crops on citrus orchards growth and fruiting under Toshka conditions. J. Agric. Vet. Sci. 1: 101-110.

Akyeapong, E., Hitimana, L. and Munyemana, P. C. 1999. Multistrata Agroforestry with beans, bananas and Grevilla rubusta in the highlands of Burundi, Expt. Agric., 35: 357369.

Anburani, A. and Vidhya Priyadharshini, H. 2011. Effect of intercropping on growth in mullai (Jasminum auriculatum). International $J$. Agric. Sci. 7(1): 156-158

Anonymous, 2017. Horticultural Statistics at a Glance 2017 - National Horticulture Board.

Asandhi, A. A. 1994. Effect of corn, sweet potato and yardlong bean intercropping on growth and yield of potato. AGRIS. http://agris.fao.org/agrissearch/search.do?recordID=PH9410371

Bhatnagar, P., Kaul, M. K. and Singh, J. 2007. Effect of intercropping in Kinnow based production system. Indian J. Arid Hort. 2: $15-17$.

Bhuva, H. P., Katrodia, J. S., Patel, G. and Chundawat, B. S. 1985. Response of intercropping on economics and effects on main crop of mango under south Gujrat conditions. Second international symposium on mango, Banglore, India, 2024 May 1985. 
Chowdhury, D. and Deka, K. K. 1997. Coconut based inter mixed cropping under Assam conditions. J. Plantation Crops. 25(1): 106108.

Gadre, N. A. 1997. Economics of production of papaya for papain production. P.K.V. Research-Journal. 21(2): 142- 145.

Ghosh, S. N. and Pal, P. P. 2010. Effect of intercropping on plant and soil of Mosambi sweet orange orchard under rainfed conditions. Indian J. Hort. 67(2): 185-90.

Gold, C. S., Karamura, E. B., Kiggunda, A. and Baganda, F. A. 1999. Geographic shifts in highland banana (Musa group A A A-E). Production in Uganda. Afric. Crop. Sc. Jnl. 10(2): 20-25.

Kashyap, R., J. Singh and Beohar, B. B. 1989. Economics of intercropping in newly planted mango orchard with guava as filler crop in eastern Madhya Pradesh. International Symposium on Horticultural Economics in Developing Countries, Atemaya (Ethiopia).

Kumar, S., Swaminathan, V. and Sathiamoorthy, S. 2000. Effect of spacing, nutrition and intercrops on yield and quality of papaya (Carica papaya L.). Research on Crops, 1(1): 58-62.

Panse, V. G. and Sukhatme, P. V. 1995. Statistical Method for Agricultural Workers. $4^{\text {th }}$ edition, ICAR Pub., New Delhi. pp 162.

Rajput, M. S., K. C. Srivastava and V. Shukla 1986. Intercropping in young mango orchard. Acta. Hortic., 231(1) : 312-315.

Salam, M. A. and Peter, K. V. 2010. CASHEW - A Monograph. Studium Press (India) Pvt. Ltd, New Delhi-110 002. pp. 282.

Sarkar, S. K., Gautam, B., Seethambram, Y. and Vijaya, N. 2004. Effect of intercropping sequence with vegetables in young mango orchard under Deccan plateau. Indian J. Hort. 61: 125-27.
Sharma, D. P. 1999. Productivity of some vegetable crops as intercrops with mango plantation. Advances in Horticulture and Forestry, 6: 31-33.

Singh, S. K. and Sharma, M. 2016. Evaluating significance of vermicompost and intercropping Amorphophallus for integrated Indian goose berry orchard management. International Journal of Agriculture Science. 8(39): 1809-1812.

Singh, S. K., Prasad, J. and Singh, P. K. 2015. Studies on economic potential of various vegetable crops as intercrops under plantation of guava (Psidium guajava L.). Bioved. 26(2): 219-222.

Swain, S. C., Dora, D. K., Sahoo, S. C., Padhi, S. K. and Sanyal, D. 2012. Influence of Mango-Based Intercropping Systems on Improvement of Soil Health under Rainfed Situation. Communications in Soil Science and Plant Analysis. 43(15): 2018-2026.

Taweekiat, Y., Sumrit, F. and Sorot, C. 1989. Inter-cropping in cashew nut plot. Agriculture J. 17(4): 266-270. (Khon Kaen Univ., Faculty of Agriculture, Dept. of Hort., Thailand).

Tiwari, R. and Baghel, B. S. 2014. Effect of intercropping on plant and soil of Dashehari mango orchard under low productive environments. The Asian J. Horticulture. 9(2): 439-442.

Upadhyaya, R. C., Patiram and Ray, S. 1994. Decline status of mandarin orange (Citrus reticulata Blanco) in Sikkim. Journal of Hill Research. 7(2): 83-88.

Vikram, H. C., Hegde, N. K., Shivaprasad M. K. and Hari Kumar, V. 2015. Economics, land equivalent ratio and crop intensity index for cashew based intercropping system with spice crops under Zone-8 of Karnataka. Green Farming. 6(4): 836-838.

\section{How to cite this article:}

Gajbhiye. R. C., S. N. Pawar, V. K. Zote and Sawant. B. N. 2020. Intercropping of Different Vegetable Crops in New Cashew Plantation under Konkan Conditions of Maharashtra, India. Int.J.Curr.Microbiol.App.Sci. 9(06): 448-455. doi: https://doi.org/10.20546/ijcmas.2020.906.059 